\title{
RAG-1 and IgM Genes, Markers for Early Development of the Immune System in Olive Flounder, Paralichthys olivaceus
}

\author{
Jang-Wook Lee, Hyun Yang, Jae Koo Noh, Hyun Chul Kim, Choul-Ji Park, Jong-Won Park, \\ In Joon Hwang, Sung Yeon Kim and ${ }^{\dagger}$ Jeong-Ho Lee \\ Genetics and Breeding Research Center, NFRDI, Geoje 656-842, Republic of Korea
}

\begin{abstract}
Fish larvae are immediately exposed to microbes from hatching to maturation of their lymphoid organs, therefore effective innate mechanisms is very important for survival. However, the knowledge of the development of immune system in fish is limited and in demand now. In vertebrates, recombination-activating gene 1 (RAG-1) and immunoglobulin M (IgM) have been considered as very useful markers of the physiological maturity of the immune system. In this study, the expression of the both genes was assessed throughout the early developmental stages of olive flounder larvae (5-55 dph) and used as markers to follow the development of immune system. RAG-1 and IgM mRNA expression was detectable at 5 dph and remained so until $55 \mathrm{dph}$. These patterns of expression may suggest that the olive flounder start to develop its function around $5 \mathrm{dph}$. Tissue distribution was found that both genes mRNAs are only expressed in the immune-related organ such as spleen, kidney and gill. The early detection of IgM mRNA led to the investigation of its presence in oocytes. Both RAG-1 and IgM mRNA transcripts were detected in unfertilized oocytes, suggesting that they are maternally transferred. The biological significance of such a phenomenon remains to be investigated.
\end{abstract}

Key words : Olive flounder (Paralichthys olivaceus), RAG-1, IgM, Development, Expression, Maternal transfer

\section{INTRODUCTION}

The olive flounder (Paralichthys olivaceus), is widely distributed along the coast of East Asia and is one of the most economically important marine species in the region. $P$. olivaceus is successfully cultured in Japan, China and Korea. But, olive flounder faces significant mortality especially in the early stages of life, which attracted our interest to characterize how their immune system works during the development stages. In fishes, larvae are immediately exposed to various microorganisms after hatching (Zapata et al., 1997). However, the immune system is still developing and not all of the structures and functions present in the adults are in the larvae (Ellis, 1988; Tatner, 1996). Therefore, knowledge of the immune system in ontogeny can offer new protective strategies and indicate optimal vaccination point (Vadstein, 1997).

Previous studies show that the appearance of the immune organ and system during early developmental stages is different in different fish species, such as sea bream (Jósefsson \& Tatner, 1993), turbot (Padrós \& Crespo, 1996), yellowtail and olive flounder (Chantanachookhin et al., 1991). Most of these studies have been carried out using histology as the main technique to investigate the develop-

\footnotetext{
Manuscript received 22 April 2014, Received in revised form 30 April 2014, Accepted 8 May 2014

${ }^{\dagger}$ Corresponding Author : Jeong-Ho Lee, Genetics and Breeding Research Center, NFRDI, Geoje 656-842, Republic of Korea, Tel: +82-55-639-5811, Fax: +82-55-639-5809 E-mail: jhlee7124@korea.kr

This is an Open Access article distributed under the terms of the Creative Commons Attribution Non-Commercial License (http:// creativecommons.org/licenses/by-nc/3.0) which permits unrestricted non-commercial use, distribution, and reproduction in any medium, provided the original work is properly cited.
} 
ment of the immune organs in fish.

Recently, lymphoid organs and both $\mathrm{T}$ and $\mathrm{B}$ cells have been chosen to study the ontogeny of the fish immune system in various fish species, and recombination-activating gene 1 (RAG-1) and immunoglobulin M (IgM) have been considered as very useful markers of the immunological maturation (Corripio-Miyar et al., 2007; Hansen \& Kaattari, 1995; Willett et al., 1997; Peixoto et al., 2000; Huttenhuis et al., 2005; Zhang et al., 2009; Fan et al., 2009).

The RAG-1 gene is essential in the differentiation of immature $\mathrm{B}$ and $\mathrm{T}$ cells and is expressed in primary lymphoid organs, although not in mature cells (Nagaoka et al., 2000). It is this expression during the maturation of the lymphoid organs that makes the RAG-1 gene such a useful marker for the study of the development of these organs (Willett et al., 1997; Dunham, 1999). IgM is also an important gene that can be used in the study of the ontogenesis of the immune system, as it is the first formed antibody of the primary response in higher vertebrates (Magnadóttur, 1998). The presence of $\operatorname{IgM}$ has been extensively reported in many fish, including studies of its appearance during development and even maternal transfer of IgM to the offspring (Kanlis et al., 1995; Olsen \& Press, 1997; Takemura \& Takano, 1997; Picchietti et al., 2001). In teleost fish, RAG-1 and IgM has been studied in gadoid haddock (Corripio-Miyar et al., 2007), zebra fish (Willett et al., 1997), common carp (Huttenhuis et al., 2005), redspotted grouper (Mao et al., 2012) and striped trumpeter (Covello et al., 2013).

The present study aimed to improve knowledge about expression of RAG-1 and IgM in olive flounder, which can provide crucial information regarding the ontogeny of the immune system, with implications for vaccination regimes. Although the RAG-1 and IgM gene has been reported in several fish, considerably less is known about the expression of both genes in olive flounder. Therefore, we investigate the expression pattern analysis in larvae and tissue-specific expression in immune organ.

\section{MATERIALS AND METHODS}

\section{Sample preparation}

Olive flounder larvae was obtained from Genetics and Breeding Research Center, National Fisheries Research and Development Institute (NFRDI; Geoje, Republic of Korea), and maintained in 10 tons flow through tank at $20 \pm 1^{\circ} \mathrm{C}$ under a natural photoperiod. The sample was prepared from various tissues including brain, muscle, fin, eye, liver, gill, kidney, and spleen obtained from 90-dayold healthy olive flounder $(n=3)$. Different larval stages including 5 to 55 days post hatching (dph) $(5 \mathrm{dph}, 10 \mathrm{dph}$, $15 \mathrm{dph}, 20 \mathrm{dph}, 25 \mathrm{dph}, 30 \mathrm{dph}, 35 \mathrm{dph}, 40 \mathrm{dph}, 45 \mathrm{dph}$, $50 \mathrm{dph}$ and $55 \mathrm{dph}$ ) fish and unfertilized oocyte kept at $18.0^{\circ} \mathrm{C}$ in the sea-water tank. The sample of 10 randomly selected fishes were collected and immediately frozen in liquid nitrogen, and stored at $-80^{\circ} \mathrm{C}$ until RNA extraction.

\section{2. cDNA production}

Total RNA was isolated with Trizol Reagent (Invitrogen), following the manufacturer's instructions. RNA was suspended in DEPC-treated water and used for RT-PCR. The total RNA concentration was quantified by spectrophotometer and $1 \mu \mathrm{g}$ of total RNA was used for reverse transcribed into cDNA using First Strand cDNA synthesis kit (Roche). The amplification was performed with AmpliTag Gold DNA Polymerase (Applied Biosystems) in thermal Cycler (Applied Biosystems) using the following parameters: denaturation at $95^{\circ} \mathrm{C}$ for $10 \mathrm{~min}$ and 35 cycles of reactions of denaturation at $98^{\circ} \mathrm{C}$ for $10 \mathrm{sec}$, annealing at $58^{\circ} \mathrm{C}$ for $30 \mathrm{sec}$, and elongation at $72^{\circ} \mathrm{C}$ for $30 \mathrm{sec}$. An aliquot of each PCR product was subjected to $1.2 \%(\mathrm{w} / \mathrm{v})$ agarose gel electrophoresis and visualized by staining with ethidium bromide.

All the primers were designed using Primer3 (Rozen \& 
Table 1. Sequences of primers used for the RT-PCR

\begin{tabular}{cccc}
\hline \hline Gene & Primer & Sequence $\left(5^{\prime}-3^{\prime}\right)$ & $\begin{array}{c}\text { GenBank } \\
\text { accession no. }\end{array}$ \\
\hline \multirow{2}{*}{$\beta$-Actin } & Forward & GAGCGTGGCTACTCCTTCAC & CX725848 \\
& Reverse & AGGAAGGAAGGCTGGAAGAG & \multirow{2}{*}{ KC442210 } \\
\hline \multirow{2}{*}{ RAG-1 } & Forward & CTGTGCCGCTACAGCTTCAA & \multirow{2}{*}{ AB052744 } \\
& Reverse & CGGAAACGCCTGAACAGTTT & \\
\hline \multirow{2}{*}{ IgM } & Forward & TCACACCCTCCTCACTGACTTTC & TTCCTGCTTCATGCGTCACA \\
\hline
\end{tabular}

Skaletsky 2000). The gene specific primers are listed in Table 1.

\section{Expression studies}

To evaluate mRNA levels of RAG-1 and IgM, primers were specifically designed to detect and quantify cDNA sequences without detecting genomic DNA. The real-time PCR reactions were monitored with melting curve analysis using 7500 software (version 2.0.5). Amplification efficiency was determined by a serial dilutions. All experiments were repeated in triplicate. Each reactions displayed an efficiency 95.9\% $\left(\mathrm{R}^{2}=0.994\right), 96.7 \%\left(\mathrm{R}^{2}=0.997\right)$ and $98 \%\left(\mathrm{R}^{2}=0.999\right)$, RAG-1, IgM and $\beta$-actin, respectively.

Real-time PCR reaction mixture contained $2 \mu \mathrm{L}$ of diluted cDNA sample, specific primer and the FAST SYBR Green PCR Master Mix (Applied Biosystems). The reactions for the amplification of RAG-1, IgM and $\beta$-actin were subjected to an initial denaturation at $95^{\circ} \mathrm{C}$ for $20 \mathrm{sec}$, annealing at $58^{\circ} \mathrm{C}$ for $30 \mathrm{sec}$, and elongation at $60^{\circ} \mathrm{C}$ for $30 \mathrm{sec}$. Thermal cycling and fluorescence detection were conducted using the 7500 Fast Real-Time PCR system (Applied Biosystems).

Expression of RAG-1 and IgM gene was normalized to an endogenous reference $\beta$-actin and presented as subtraction of target $\mathrm{CT}$ values from $\beta$-actin $\mathrm{CT}$ values ( $\Delta \mathrm{CT}$ value). Comparison of gene expression between tissues and calibrator was derived from subtraction of the calibrator $\Delta \mathrm{CT}$ values from the target $\Delta \mathrm{CT}$ values to give a $\Delta \Delta \mathrm{CT}$ value, and relative gene expression was calculated to determine fold difference $\left(2^{-\Delta \Delta \mathrm{CT}}\right)$.

\section{Statistical analysis}

The data are presented as the mean \pm standard deviation. The mRNA levels of RAG-1 and IgM was expressed as a ratio to those $\beta$-actin, which was simultaneously amplified as an internal control for each cDNA. The data was statistically analyzed by one-way ANOVA after arcsine transformation when needed, and followed by a Tukey test for identification of the statistically distinct groups. Significant differences were accepted for $P<0.05$.

\section{RESULTS}

1. Expression of olive flounder RAG-1 and IgM from various tissues

To investigate the expression of the RAG-1 and IgM genes, oligonucleotide specific primers were designed according to previously reported both genes in olive flounder (GenBank accession no. KC442210 and AB052744, respectively) (Table 1). In order to investigate of olive flounder RAG-1 and IgM mRNA expression in various tissues, we assessed the expression of the both genes in various tissues from 90-days-old healthy olive flounder by RT-PCR (Fig. 1). It was found that RAG-1 and IgM mRNAs are significantly expressed in the spleen, kidney and gill, not expressed in other tissues. These overall patterns of RAG-1 and IgM mRNA expression were 
A

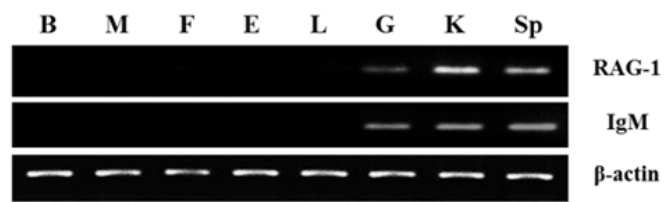

B

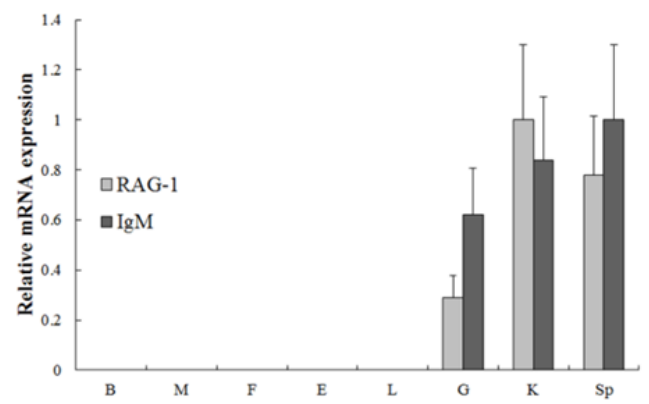

Fig. 1. Normal tissue distribution of RAG-1 and IgM mRNA in various tissues. (A) Tissue distribution of the RAG-1 and IgM mRNA was subjected to RT-PCR analysis using 90 day-old healthy olive flounder. (B) A quantitative real-time PCR analysis was performed with equal amounts of total RNA from the tissues of healthy olive flounders. $\beta$-actin was used as an internal control. B, brain; $\mathrm{M}$, muscle; F, fin; E, eye; L, liver; G, gill; K, kidney; Sp, spleen.

limited in typical immune organs. Kidney, spleen and gill were typical immune organs in teleost fish. The kidney is a major organ with key regulatory functions for the immuneendocrine interactions, and spleen as a secondary lymphatic and scavenging organ plays a crucial role in hematopoiesis, antigen degradation and antibody production processing (Rauta et al., 2012). Also, gill is the main mucosal surface and immune barriers.

\section{Expression of olive flounder RAG-1 and $\lg M$} during early development

The expression of both genes from triplicate samples was standardized using housekeeping gene $\beta$-actin. The expression pattern of the RAG-1 and IgM gene was investigated over time course $5,10,15,20,25,30,35,40$, 45, 50 and $55 \mathrm{dph}$ of olive flounder using real-time PCR. RAG-1 expression was first detected at $5 \mathrm{dph}$, and signify-
A

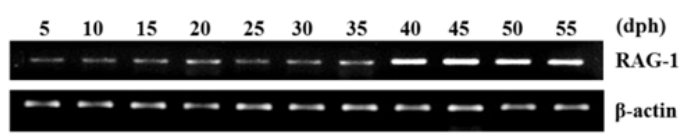

B

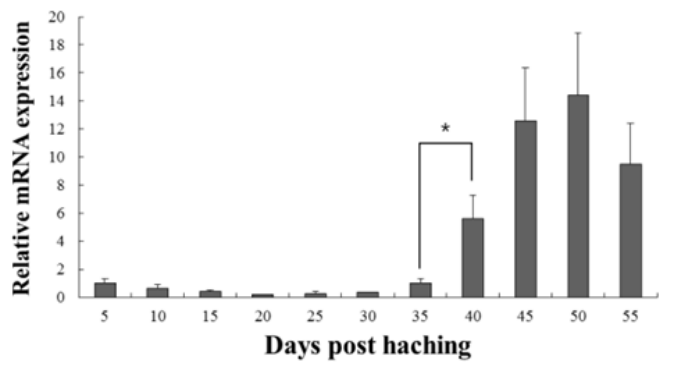

Fig. 2. Expression of RAG-1 mRNA at different developmental stages. (A) Larvae sample was harvested during 5 to 55 days post hatching. The RNA extracted and analyzed by RT-PCR method. (B) The mRNA expression of RAG-1 was analyzed by real-time PCR. Different letters over each bar with the standard deviation represent significant differences one group according to unpaired matched comparisons $\left({ }^{*} P<0.05\right)$.

cant expression was observed in the 40, 45, 50 and $55 \mathrm{dph}$ (Fig. 2). The intensity of RAG-1 transcript was measured on the basis of $5 \mathrm{dph}$ (1.0-fold), each value has the $40 \mathrm{dph}$ (5.6-fold), 45 dph (12.6-fold), $50 \mathrm{dph}$ (14.5-fold) and 55 dph (9.5-fold), respectively. IgM mRNA transcripts were first detected at $5 \mathrm{dph}$, and the transcription level was increased obviously in the $35 \mathrm{dph}$ (Fig. 3). The intensity of IgM transcript was measured on the basis of $5 \mathrm{dph}$ (1.0fold), each value has the $35 \mathrm{dph}$ (4.9-fold), $40 \mathrm{dph}$ (8.3fold), $45 \mathrm{dph}$ (16.1-fold), $50 \mathrm{dph}$ (23.7-fold) and $55 \mathrm{dph}$ (15.5-fold), respectively. As RAG-1 and IgM mRNA was detected earlier than expected $(5 \mathrm{dph})$, the possibility of maternal mRNA transfer into oocytes was investigated. It was found that both RAG-1 and IgM mRNA transcripts were present in unfertilized oocytes (Fig. 4). Studies on several fish species have shown that RAG-1 and IgM are transferred from the mother to the offspring (Covello et al., 2013; Takemura \& Takano, 1997), and may be involved in the early defense against pathogen in eggs containing 


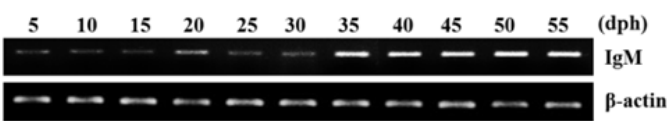

B

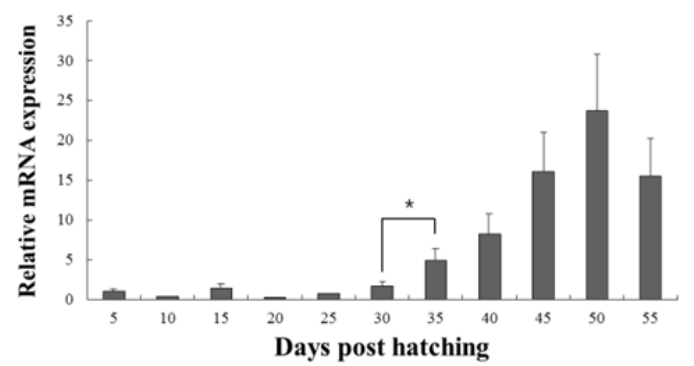

Fig. 3. Expression of IgM mRNA at different developmental stages. (A) Different twelve stages of larval stages including 5 to 55 days post hatching (dph). The RNA extracted and analyzed by RTPCR method. (B) The mRNA expression of IgM was analyzed by real-time PCR. Different letters over each bar with the standard deviation represent significant differences one group according to unpaired matched comparisons $\left({ }^{*} P<0.05\right)$.

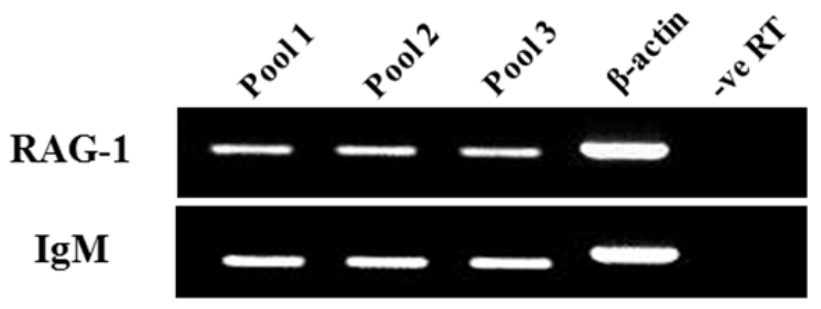

Fig. 4. Expression of RAG-1 and IgM mRNA in unfertilized oocytes. Represents the expression of RAG$1, \operatorname{IgM}$ and $\beta$-actin in unfertilized oocytes measured in three separate pools. The negative (-ve) RT controls contain RNA from each time point that was not reverse transcribed and therefore acts as evidence that the samples were free of contaminating genomic DNA.

developing embryo and larvae.

\section{DISCUSSIONS}

Because of the importance of immune response, many studies have been conducted in fish during the early larvae stages. This study is the first to report the mRNA expression of the important immune genes RAG-1 and IgM in the olive flounder. In addition their expression was followed from unfertilized oocytes through to the early developmental stage of the larvae. As both genes are important markers of the ontogeny of the adaptive immune response, their level of expression can help from the problem of high mortality in olive flounder larvae. In teleost fish, the RAG1 mRNA level was first examined in lymphoid organs of rainbow trout larvae (Hansen \& Kaattari, 1995), and also investigated in the same organs of zebra fish (Willett et al., 1997) and common carp (Huttenhuis et al., 2005). Humoral adaptive immunity in fish is mediated by $\operatorname{Ig}$, and the $\operatorname{IgM}$ class is the primary immunoglobulin in most teleost fish. The IgM class has been studied in many species such as salmon (Hatten et al., 2001), zebra fish (Danilova et al., 2000), Atlantic cod (Schrøder et al., 1998) and rainbow trout (Lee et al., 1993).

In our study, RAG-1 and IgM mRNA was investigated in various tissues including brain, muscle, fin, eye, liver, gill, kidney, and spleen (Fig. 1). The results confirmed in both genes that the spleen, kidney and gill are the typically immune organs in teleost fish species, since the differrentiation of early $\mathrm{T}$ and $\mathrm{B}$ cells occur in the tissues. In previous study, IgM gene was isolated and identified from the cDNA clones in olive flounder BAC library, and confirmed expression levels of various tissues using RTPCR (Hirono et al, 2003). The results are similar with our study, showed that IgM transcript level was detected in spleen and kidney. In contrast, these results are conflicted with IgM expression studies in the red-spotted grouper (Mao et al., 2012), where IgM expression appeared to be ubiquitous and constitutive, except the gonad.

Fish larvae are exposed to pathogens a long period before of time until maturation of their lymphoid organs, therefore information of immune gene may be essential for survival (Zapata et al., 1997). However, the mRNA expre- 
ssion analysis of RAG-1 and IgM during the early developmental stage in olive flounder is insufficient. In this study, to information of RAG-1 and IgM expression during early larvae stages of development, we analyzed the expression pattern of both genes after hatching. As a result, RAG-1 and IgM mRNA was first detected in $5 \mathrm{dph}$, observed the increased mostly until 50 dph (Fig. 2). Significant expression of RAG-1 was detected in 40 to $55 \mathrm{dph}$, while IgM was detected in 35 to $55 \mathrm{dph}$. In our study, the immune system of $\mathrm{B}$ and $\mathrm{T}$ cell marked by RAG-1 and IgM starts to develop its function around $5 \mathrm{dph}$ in olive flounder. The patterns of RAG-1 expression levels, they did not follow the trend of an initial increase in $\operatorname{IgM}$ mRNA expression. Studies in striped trumpeter have shown a similar pattern of RAG-1 and IgM expression, but with some variation in the peak expression patterns (Covello et al., 2013). This early detection of IgM mRNA led to the investigation of transcript presence in unfertilized oocytes (Fig. 4). Both RAG-1 and IgM mRNA were present in oocytes, leading to the conclusion that they were maternally transferred.

In summary, this study provides the information of RAG-1 and IgM mRNA expression during the early developmental stage in olive flounder. These expression pattern of both genes in tissue distribution and developmental stage shows that may play an important function in the early immune response of olive flounder larvae. This study is the first to report the mRNA expression of the important immune genes RAG-1 and IgM in the olive flounder. This will allow the timing of vaccination of fish to be optimized so as to allow protection at the earliest time possible, to help reduce the high mortalities seen during the early stages of development.

\section{ACKNOWLEDGEMENT}

This work was supported by a grant from the National
Fisheries Research and Development Institute (NFRDI), contribution number RP-2014-BT-014.

\section{REFERENCES}

Chantanachookhin C, Seikai T, Tanaka M (1991) Comparative study of the ontogeny of the lymphoid organs in three species of marine fish. Aquaculture 99:143155.

Corripio-Miyar Y, Bird S, Treasurer JW, Secombes CJ (2007) RAG-1 and IgM genes, markers for early development of the immune system in the gadoid haddock, Melanogrammus aeglefinus, L. Fish Shellfish Immunol 23:71-85

Covello JM, Bird S, Morrison RN, Bridle AR, Battaglene SC, Secombes CJ, Nowak BF (2013) Isolation of RAG-1 and IgM transcripts from the striped trumpeter (Latris lineata), and their expression as markers for development of the adaptive immune response. Fish Shellfish Immunol 34:778-788.

Danilova N, Hohman VS, Kim EH, Steiner LA (2000) Immunoglobulin variable region diversity in the zebra fish. Immunogenetics 52:81-91.

Dunham M (1999) ika1 and rag1 as markers of the development of the zebra fish immune system. BUG journal 2:49-53.

Ellis AE (1988) Ontogeny of the immune system in teleost fish. In: Ellis AE (ed) Fish Vaccination Academic Press, London, pp.20-31.

Fan SG, Zhang QY, Luo C (2009) Sequence cloning and expression analysis of RAG genes in goldfish. Acta Hydrobiologica Sin 33:603-612.

Hansen JD, Kaattari SL (1995) The recombination activating gene 1 (RAG1) of rainbow trout (Oncorhynchus mykiss): cloning, expression, and phylogenetic analysis. Immunogenetics 42:188-195.

Hatten F, Fredriksen Å, Hordvik I, Endresen C (2001) 
Presence of $\operatorname{IgM}$ in cutaneous mucus, but not in gut mucus of Atlantic salmon, Salmo salar. Serum IgM is rapidly degraded when added to gut mucus. Fish Shellfish Immunol 11:257-268.

Hirono Ikuo, Nam B-H, Enomoto J, Uchino K, Aoki T (2003) Cloning and characterization of a cDNA encoding Japanese flounder Paralichthys olivaceus IgD. Fish Shellfish Immunol 15:63-70.

Huttenhuis HBT, Huisinga MO, Meulen T, Oosterhoud CN, Sánchez NA, Taverne-Thiele AJ, Strobandc HWJ, Rombouta HWM (2005) Rag expression identifies B and $\mathrm{T}$ cell lymphopoietic tissues during the development of common carp (Cyprinus carpio). Dev Comp Immunol 29:1033-1047.

Jósefsson S, Tatner MF (1993) Histogenesis of the lymphoid organs in sea bream (Spaurus aurata L.). Fish Shellfish Immunol 3:35-49.

Kanlis G, Suzuki Y, Tauchi M, Numata T, Shirojo Y, Takashima F (1995) Immunoglobulin in oocytes, fertilized eggs, and yolk sac larvae of red sea bream. Fish Sci 61:787-790

Lee MA, Bengtén E, Daggfeldt A, Rytting AS, Pilström L (1993) Characterisation of rainbow trout cDNAs encoding a secreted and membrane-bound Ig heavy chain and the genomic intron upstream of the first constant exon. Mol Immunol 30:641-648.

Magnadottir B (1998) Comparison of immunoglobulin (IgM) from four fishes. Buvisindi Ice Agr Sci 12:47-59.

Mao M-G, Lei J-L, Alex P-M, Hong W-S, Wang K-J (2012) Charaterization of RAG1 and IgM (mu chain) marking development of the immune system in redspotted grouper (Epiniphelus akaara). Fish Shellfish Immunol 33:725-735.

Nagaoka H, Yu W, Nussenzweig MC (2000) Regulation of RAG expression in developing lymphocytes. Curr Opin Immunol 12:187-190.

Olsen YA, Press CML (1997) Degradation kinetics of immunoglobulin in the egg, alevin and fry of Atlantic salmon, Salmo salar L., the localisation of immuneglobulin in the egg. Fish Shellfish Immunol 7:81-91.

Padrós F, Crespo S (1996) Ontogeny of the lymphoid organs in the turbot Scophthalmus maximus: a light and electron microscope study. Aquaculture 144:1-16.

Peixoto BR, Mikawa Y, Brenner S (2000) Characterization of the recombinase activating gene- 1 and 2 locus in the Japanese pufferfish, Fugu rubripes. Gene 246:275-283.

Picchietti S, Scapigliati G, Fanelli M, Barbato F, Canese S, Mastrolia L, Mazzini M, Abelli L (2001) Sex-related variations of serum immunoglobulins during reproduction in gilthead sea bream and evidence for a transfer from the female to the eggs. J Fish Biol 59:1503-1511.

Rauta PR, Nayak B, Das S (2012) Immune system and immune responses in fish and their role in comparative immunity study: a model for higher organisms. Immunol Lett 148:23-33.

Rozen S, Skaletsky HJ (2000) Primer3 on the WWW for general users and for biologist programmers. In: Misener, S. \& S. A. Krawetz (Eds) Bioinformatics Methods and Protocols: Methods in Molecular Biology Humana Press Inc, Totowa (NJ), pp.365-386.

Schrøder MB, Flano E, Pilstrøm L, Jørgensen TØ (1998) Localisation of Ig heavy chain mRNA positive cells in Atlantic cod (Gadus morhua L.) tissues; identified by in situ hybridization. Fish Shellfish Immunol 8:565576 .

Takemura A, Takano K (1997) Transfer of maternallyderived immunoglobulin ( $\operatorname{IgM})$ to larvae in tilapia, Oreochromis mossambicus. Fish Shellfish Immunol 7: 355-363.

Tatner MF (1996) Natural changes in the immune system of fish. In: Iwama, G, Nakanishi T (Eds) The Fish Immune System Organism, Pathogen and Environment Academic Press, San Diego, CA, pp.255-287.

Vadstein O (1997) The use of immunostimulation in marine 
larviculture: possibilities and challenges. Aquaculture 155:401-417.

Willett CE, Cherry JJ, Steiner LA (1997) Characterization and expression of the recombination activating genes (rag1 and rag2) of zebra fish. Immunogenetics 45:394404.
Zapata AG, Torroba M, Varas A, Jiménez E (1997) Immunity in fish larvae. Dev Biol Standardizations 90:23-32.

Zhang QY, Fan SG, Luo C (2009) Sequence cloning and expression analysis of recombination active gene 1 and 2 in grass carp, Ctenopharyngodon idellus. Acta Hydrobiologica Sin 33:795-803. 